\title{
Retrospective Analysis of AMATEM Patients Treated in Psychiatry Inpatient Unit of Adiyaman Training and Research Hospital: Data for 2018
}

\section{Adıyaman Eğitim ve Araştırma Hastanesi Psikiyatri Servisinde Tedavi Gören AMATEM Hastalarının Geriye Dönük Olarak İncelenmesi: 2018 Yılı Verileri}

(iD Oğuzhan Bekir EĞILMEZ1, (iD Mehmet Hamdi ÖRÜM², iD Mahmut Zabit KARA3

'Adiyaman University Faculty of Medicine, Department of Psychiatry, Adiyaman, Turkey

2Kahta State Hospital, Clinic of Psychiatry, Adiyaman, Turkey

${ }_{3}^{3}$ University of Health Science Antalya Training and Research Hospital, Clinic of Child and Adolescent Mental Health and Diseases, Antalya,

Turkey

\section{ABSTRACT}

Objective: The prevalence of substance use disorder (SUD) is increasing in the world and in our country. The most important centres in the treatment of SUD in Turkey are Alcohol and Drug Addiction Treatment and Research Centres (AMATEM). In this study, we aimed to investigate the substance use characteristics of the patients who were hospitalized in our hospital.

Method: The study was conducted as a retrospective study of AMATEM admissions between January 1, 2018 and December 31, 2018. Data such as gender, age and substance use characteristics were obtained from the patient recording system.

Results: Forty-two male patients (91.3\%) and 4 (8.7\%) female patients were included in the study. The mean age of the patients was $28.43 \pm 10.64$ years. There were 10 patients $(21.7 \%)$ with opiate use disorder (OUD), 14 patients (30.4\%) with cannabis use disorder (CUD), 12 (26.1\%) patients with alcohol use disorder (AUD), 3 (6.5\%) patients with stimulant use disorder (SIUD), and 7 (15.2\%) patients with inhalant use disorder (IUD). The mean age of AUD was significantly higher than the other groups $(\mathrm{p}=0.010)$. The mean duration of hospitalization was $7.63 \pm 7.01$ days $(\mathrm{p}=0.073)$. The mean number of hospitalizations was $2.78 \pm 2.61(\mathrm{p}=0.874)$. The mean

\section{ÖZ}

Amaç: Madde kullanım bozukluğunun (MKB) yaygınlığı, dünyada ve ülkemizde giderek artmaktadır. Ülkemizde MKB tedavisinde en önemli merkezler Alkol ve Uyuşturucu Madde Bağımlıları Tedavi ve Araştırma Merkezleri'dir (AMATEM). Biz bu çalışmada hastanemizde yatarak tedavi gören MKB tanılı hastaların madde kullanım karakteristiklerini incelemeyi amaçladık.

Yöntem: Çalışma, 1 Ocak 2018-31 Aralık 2018 tarihleri arasındaki AMATEM başvurularının retrospektif olarak incelenmesi şeklinde gerçekleştirildi. Başvurulara ait cinsiyet, yaş ve madde kullanım özellikleri gibi bilgilere hasta kayıt sisteminden ulaşıldı.

Bulgular: Çalışmaya $42(\% 91,3)$ erkek, $4(\% 8,7)$ kadın olmak üzere

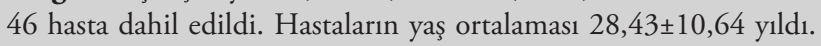
On $(\% 21,7)$ hastanın opiat kullanım bozukluğu (OPKB) tanısı, $14(\% 30,4)$ hastanın esrar kullanım bozukluğu (EKB) tanısı, 12 $(\% 26,1)$ hastanın alkol kullanım bozukluğu (AKB) tanısı, $3(\% 6,5)$ hastanın stimülan kullanım bozukluğu (SKB) tanısı, 7 (\%15,2) hastanın inhalan kullanım bozukluğu (İKB) tanısı vardı. AKB grubunun yaş ortalaması anlamlı olarak diğer gruplardan yüksekti

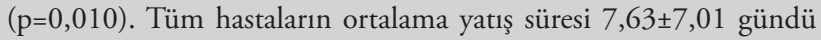
$(\mathrm{p}=0,073)$. Tüm hastaların ortalama yatış sayısı $2,78 \pm 2,61$ idi. Tüm

Address for Correspondence: Mehmet Hamdi ÖRÜM, Kahta State Hospital, Clinic of Psychiatry, Adiyaman, Turkey

E-mail: mhorum@hotmail.com ORCID ID: orcid.org/0000-0002-4154-0738

Cite this article as: Eğilmez OB, Örüm MH, Kara MZ. Retrospective Analysis of AMATEM Patients Treated in Psychiatry Inpatient Unit of Adiyaman Training and Research Hospital: Data for 2018. Bezmialem Science 2020;8(2):106-12. 
duration of substance use was $9.67 \pm 8.73$ years. The duration of substance use was significantly higher in the AUD group ( $\mathrm{p}=0.001)$. Thirty-six $(78.3 \%)$ of all patients had a forensic history. Twenty-one $(45.7 \%)$ of the patients needed hibernation. Ten $(21.7 \%)$ of the patients had suicide attempt history. Twenty-eight $(60.9 \%)$ of the patients had homicidal behaviour. Psychotic symptoms were present in $15(32.6 \%)$ patients. Homicidal behaviour was significantly higher in patients with forensic history $(\mathrm{p}=0.024)$. The forensic history was significantly lower in the AUD group than in the other diagnoses $(\mathrm{p}=0.009)$.

Conclusion: SUD was accompanied by additional psychiatric symptoms. SUD was clearly related with crime. Further studies are needed to develop more robust strategies.

Keywords: Substance use disorder, AMATEM, suicide attempt, forensic history, hibernation grupların ortalama yatış süreleri benzerdi $(\mathrm{p}=0,874)$. Tüm grubun ortalama madde kullanım süresi $9,67 \pm 8,73$ yıldı. Madde kullanım süresi $\mathrm{AKB}$ grubunda anlamlı olarak daha yüksekti $(\mathrm{p}=0,001)$. Hastaların 36'sının $(\% 78,3)$ adli bir öyküsü vardı. Hastaların 21 'inde $(\% 45,7)$ hibernasyona ihtiyaç duyulmuştu. Hastaların 10 'unun $(\% 21,7)$ özkıyım girişimi öyküsü mevcuttu. Hastaların 28 'i $(\% 60,9)$ homisidal davranış sergiliyordu. Hastaların 15 'inde $(\% 32,6)$ psikotik semptom vardı. Adli öyküsü olanlarda homisidal davranış belirgin olarak yüksekti $(\mathrm{p}=0.024)$. Adli öykü $A K B$ grubunda diğer gruplara göre anlamlı olarak düşüktü ( $\mathrm{p}=0.009)$.

Sonuç: MKB, ek psikiyatrik semptomların eşlik ettiği; suç ilişkisi belirgin olarak bulunan bir durumdur. Daha sağlam stratejilerin geliştirilebilmesi için gelecek çalışmalara ihtiyaç vardır.

Anahtar Sözcükler: Madde kullanım bozukluğu, AMATEM, özkıyım girişimi, adli öykü, hibernasyon

\section{Introduction}

Substance use is as old as human history. Substance use disorder (SUD) and problems have become more important in the last few decades in psychiatry. Substance use causes people to experience social, economic and personal problems. Patients use an increasing amount of substance due to the growing tolerance. This causes them to live more physical and mental problems than others (1-4). Dependency affects the brain and therefore behaviour. The person who starts to experience more problems with his/her environment is in a vicious circle (5-7). In addition to the genetic characteristics in the emergence of addiction, environmental characteristics play an important role in the maintenance of drug addiction. On the other hand, biological processes contribute to continuity $(8,9)$. Considering that many different substances are addictive, treatment modalities for substances are also different. Treatment also varies depending on the characteristics of the person and on the problems associated with substance use (10-12). In addition, the presence of mental, occupational, general medical and social problems in many patients makes the treatment of addiction difficult. Drug addiction treatment consists of behavioural therapy (counselling, cognitive therapy and other psychotherapies), drug therapy, and a combination of these treatments $(13,14)$.

The leading centres in the treatment of SUD in Turkey are Alcohol-Drug Addiction Research, Treatment and Training Centers (AMATEM) and they have been in service since the 1980 s and the number of centers has increased. It is possible to say that these centers, where outpatient or inpatient services can be provided, have made some significant progress in our country, although it is early to say that they are in a certain standard. These clinics serve for termination of substance addiction and refunctioning of individuals. Treatment strategies are determined according to the individual because of the change in the risk factors of SUD (13). Inspection services in these centers are voluntary. As a result of the examination, the treatment plan is explained to the person and to his/her relatives and the treatment process is started. If necessary, hospitalization is made. The combination of buprenorphine+naloxone could be started with a specific protocol and the treatment process continued to be followed up, frequently. The studies about the patients who are being treated in AMATEM clinics are reached through the literature $(13,14)$.

In AMATEM units, it is possible to determine the disease-related profiles of the patients who are being treated, to determine the treatment efficiencies and to make new plans. Savaşan et al. (15) stated that the average age of the patients was 45.42 (year) and the male percentage was $96.9 \%$ based on the data of an inpatient AMATEM unit in Izmir province between 2011 and 2012. In this study, $78 \%$ of the patients were diagnosed as having AUD, $6 \%$ as having illicit substance use disorder, and $16 \%$ as having AUD plus illicit substance use disorder. Savaşan et al. (15) emphasized that individual or group psychotherapy programs to be organized within the first six months or one year might be beneficial for relapse prevention. Karaağaç et al. (16) retrospectively examined the patients who were followed-up in an AMATEM hospital in Kayseri province between 2007 and 2015 and found that the percentage of males were $94.8 \%$ and the mean age of patients was 33.6 years. In addition, the mean age of the patients with AUD was higher than the drug users and the most common cause of admission was AUD (37.2\%) and cannabis use disorder (CUD) (34.1\%). Bulut et al. (17) evaluated AMATEM data of 2001-2005 in Gaziantep province and found that the percentage of men was $96.8 \%$, the mean age was 36.02 years, the rate of patients with AUD diagnosis was $46.8 \%$, the rate of patients with opiate use disorder (OUD) was $42.1 \%$ and the rate of patients with CUD was $7.1 \%$. The data of the AMATEM clinics changed according to the years of the studies. Eğilmez et al. (13) reported that $97.8 \%$ of the 401 patients were male and the mean age was 25.75 years in Adiyaman province. According to their study, mean age of patients with AUD was significantly higher than patients with other diagnoses; $89.6 \%$ of the patients were in the age range of $20-29$ years; $84.8 \%$ of the patients were diagnosed as having OUD; recurrent admissions were significantly higher in patients with OUD than patients with other disorders. Eğilmez et al. (13) emphasized that the use of opiates in Adiyaman province 
was a serious problem. According to our literature review, a study on AMATEM inpatient data in Adiyaman province was not performed before. Considering that AMATEM data shows regional changes, interventions based on regional differences will be beneficial (14). In addition, it is thought that the data of Adiyaman province will provide comparison with AMATEM studies in different regions with similar characteristics. In this study, we aimed to retrospectively examine the patients who were admitted in our AMATEM inpatient clinic within one-year period.

\section{Method}

\section{Study Design}

Our study was planned retrospectively. The patients who met the DSM-5 (18) diagnostic criteria in the psychiatry department of Adiyaman University Training and Research Hospital and the patients withat least one substance in their urine toxic screenings were found through the patient registry system and were included in the study. The diagnostic category was determined according to the verbal declarations of the type of substance they preferred frequently and the declarations were consistent with the results of the toxic screening in the urine and patients with OUD, CUD, AUD, inhalant use disorder (IUD), stimulant use disorder (SIUD), hallucinogenic use disorder (HUD) were determined. All these steps were performed by an experienced psychiatrist (OBE). Sociodemographic data such as age, gender, and disease diagnoses were obtained from the patients registry system. A total of 55 records of hospitalized AMATEM patients were obtained. Nine of them were excluded from the study, whose diagnosis was not known and could not be confirmed due to toxic screening in urine. Forty-six hospitalizations were included in the study. In this study, the number of admissions was taken into consideration. So, there might be more than one application belonging to the same person. Ethics committee approval was obtained from Adiyaman University Non-Invasive Clinical Research Ethics Committee for this study (2019/3-6).

\section{Biochemical Analysis}

Biochemical analysis was performed in the laboratory of our hospital by means of "Instant-View Multi-Drug Abuse Urine Test Kit”. All analyses were performed between 09:00 a.m. and 15:00 a.m. The urine toxic scans of the patients who were hospitalized in the AMATEM service were requested after a short examination and performed with the detailed examination test results. In our laboratory, biochemical analysis of drug was performed by immunochromatographic methods.

\section{Statistical Analysis}

Statistical analysis was performed using the Windows SPSS 22.0 program. Descriptive statistics and continuous variables were given as mean \pm standard deviation and categorical variables were given as frequency and percentage. Independent sample t-test was used to evaluate the differences in means between the two groups. Chi-square test was used to analyse categorical data. ANOVA was used for multiple comparisons. A p value $<0.05$ was accepted as statistically significant.

\section{Results}

Forty-two male patients (91.3\%) and 4 (8.7\%) female patients were included in the study. The mean age of the patients was $28.43 \pm 10.64$ years. The mean age of the males was $28.67 \pm 10.94$ years and the mean age of the females was $26.00 \pm 7.34$ years $(\mathrm{p}=0.543)$.

There were 10 patients (21.7\%) with OUD, 14 patients (30.4\%) with CUD, 12 (26.1\%) patients with AUD, 3 (6.5\%) patients with SIUD, 7 (15.2\%) patients with IUD. The mean age of OUD was $24 \pm 5.56$ years, the mean age of CUD was $26.57 \pm 9.26$ years, the mean age of AUD was $37.25 \pm 14.24$ years, the mean age of SIUD was $20.67 \pm 4.61$ years, and the mean age of IUD was $26.57 \pm 2.99$ years. The mean age of AUD was significantly higher than other groups $(\mathrm{p}=0.010)$. The mean duration of hospitalization was $7.63 \pm 7.01$ days in all patients. The mean duration of hospitalization in patients with OUD was 5.00 \pm 3.97 days, with CUD was $11.29 \pm 9.83$ days, with AUD was $8.50 \pm 5.46$ days, with SIUD was $2.00 \pm 1.73$, and with IUD was $5.00 \pm 3.41$ days. The mean duration of hospitalization was similar ( $\mathrm{p}=0.073)$. The mean number of hospitalization in whole group was $2.78 \pm 2.61$, in OUD group was $2.70 \pm 1.49$, in CUD group was $2.36 \pm 2.00$, in AUD group was $3.25 \pm 4.33$, in SIUD group was $2.00 \pm 1.00$, and in IUD group was $3.29 \pm 1.60$. The mean duration of hospitalization was similar $(\mathrm{p}=0.874)$. The mean substance use duration in total was $9.67 \pm 8.73$ years, in OUD group was $5.40 \pm 2.45$ years, in CUD group was $7.21 \pm 4.54$ years, in AUD group was $18.08 \pm 12.95$ years, in SIUD group was $4.67 \pm 0.57$ years, and in IUD group was $8.43 \pm 3.25$ years. The duration of substance use was significantly higher in the AUD group ( $\mathrm{p}=0.001)$ (Table 1$)$. Thirty-six $(78.3 \%)$ of all patients had a forensic history.

Eighteen (39.1\%) patients received anxiolytic treatment during hospitalization, 42 (91.3\%) antipsychotics, 25 (54.3\%) antidepressants and $3(6.5 \%)$ mood stabilizers. Twenty-one (45.7\%) patients needed hibernation (it is the creation of a state of inactivity with psychotropic drugs, preferably with $10 \mathrm{mg}$ haloperidol intramuscularly plus $5 \mathrm{mg}$ biperiden intramuscularly). Ten $(21.7 \%)$ patients had suicide attempt history. Two (4.3\%) patients had suicidal thoughts at admission. Twenty-eight (60.9\%) patients had homicidal behaviour. Thirty (65.2\%) patients were discharged after the treatment was completed and $16(34.8 \%)$ were discharged upon their own request. Psychotic symptoms were present in $15(32.6 \%)$ patients.

The forensic history was significantly lower in the AUD group compared with other diagnoses $(\mathrm{p}=0.009)$. There was no significant difference between the groups in terms of anxiolytic, antipsychotic, antidepressant and mood stabilizers use $(\mathrm{p}=0.114$, $\mathrm{p}=0.254, \mathrm{p}=0.059$ and $\mathrm{p}=0.431$, respectively). The need for hibernation was significantly higher in the CUD group ( $\mathrm{p}=0.044)$. There was no significant difference between the diagnostic groups in terms of suicide attempt history $(\mathrm{p}=0.545)$. There was no significant difference between the diagnostic groups in terms of active suicide thoughts $(\mathrm{p}=0.311)$. Homicidal behaviour was significantly higher in CUD and IUD groups $(\mathrm{p}=0.000)$. There 
was no significant difference between groups in terms of type of discharge ( $\mathrm{p}=0.064)$. The psychotic symptoms were significantly higher in the CUD group $(\mathrm{p}=0.003)$.

There was no difference in the type of discharge in the OUD group $(\mathrm{p}=0.720)$. There was no difference in the need for hibernation when patients with OUD were accepted as first group and the others were accepted as second group ( $\mathrm{p}=0.066$ ). When patients with AUD were evaluated as one group and the remaining patients as a second group, the use of anxiolytic drugs was significantly higher in AUD group ( $p=0.023)$. When AUD patients were evaluated as one group and the remaining patients as a second group, forensic history was significantly lower in AUD group $(\mathrm{p}=0.000)$. When AUD patients were evaluated as one group and the remaining patients as a second group, there were no significant differences between groups in terms of the need for hibernation, suicide attempt history, active suicide thoughts, homicidal behaviour, type of discharge, and psychotic symptoms $(\mathrm{p}=0.725, \mathrm{p}=0.190, \mathrm{p}=0.390, \mathrm{p}=0.113, \mathrm{p}=0.408$ and $\mathrm{p}=0.171$, respectively). There was no relationship between forensic history and need for hibernation, suicide attempt history, suicidal thoughts, and type of discharge $(\mathrm{p}=0.261, \mathrm{p}=0.880, \mathrm{p}=0.322$ and

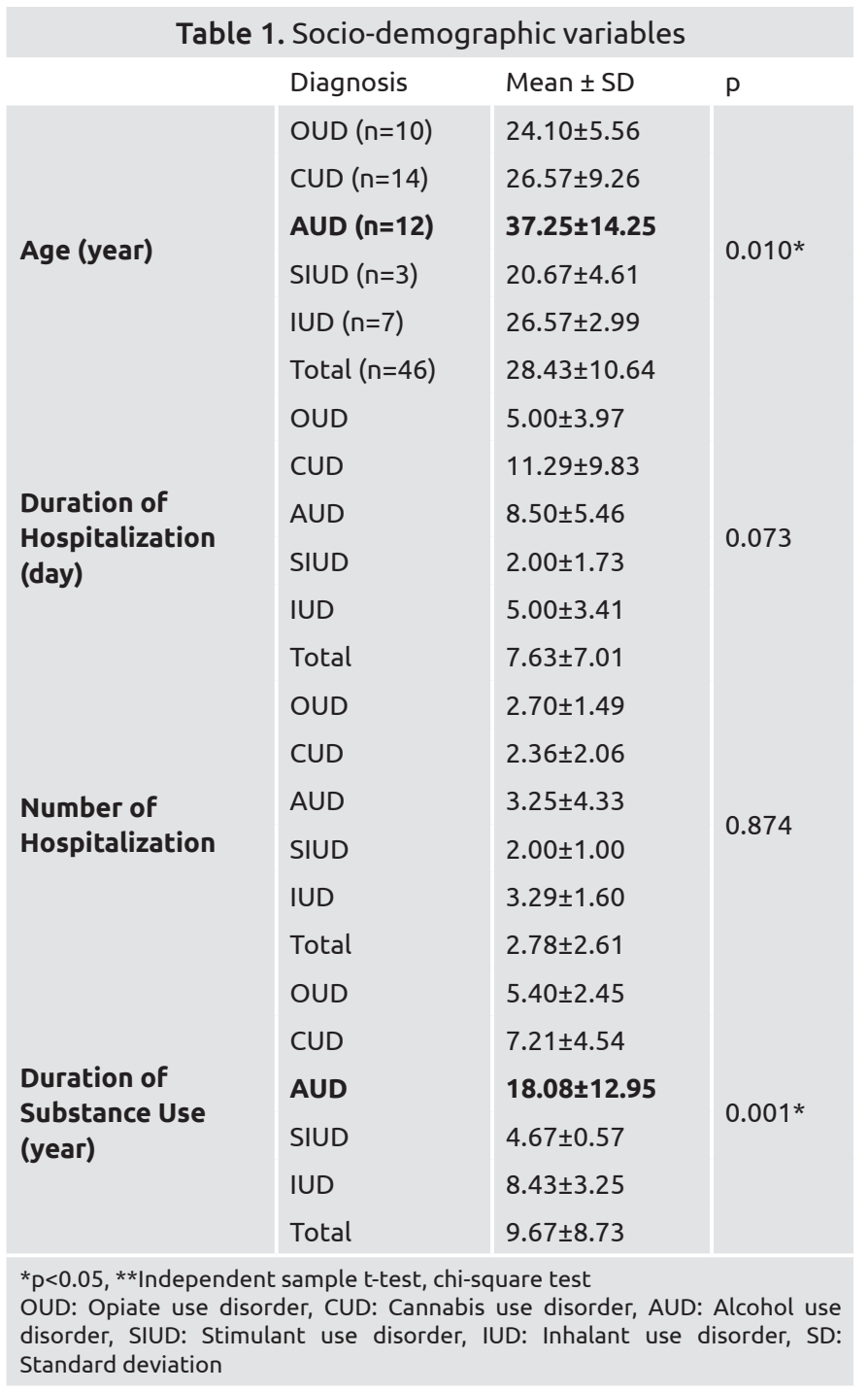

$\mathrm{p}=0.267$, respectively). Homicidal behaviour was significantly higher in patients with forensic history $(\mathrm{p}=0.024)$.

\section{Discussion}

Our study was based on one-year period in a province and showed the substance use characteristics of patients admitted in AMATEM inpatient clinic. The majority of the patient group consisted of men. The mean age was similar between males and females and was between 20 and 30 years of age. These findings were consistent with the literature. Savaşan et al. (15) found that the mean age of AMATEM patients was 45.42 years and the male percentage was $96.9 \%$. Again in that study, $78 \%$ of the patients had AUD, $6 \%$ had SUD and 16\% had AUD and SUD. In that study, the mean age was higher in patients with AUD than the others. In our study, the mean age of the AUD group was significantly higher than the other diagnostic groups. Karaağaç et al. (16) found that $94.8 \%$ of the AMATEM patients were male and that the mean age was 33.6 years. They also reported that the mean age of alcohol users was higher than the drug users and that the most common reason for admission was AUD (37.2\%). Egilmez et al. (13) reported that $97.8 \%$ of the 401 patients were male and the mean age was 25.75 years. According to that study, mean age was significantly higher in patients with AUD than patients with other diagnoses.

Alcohol use disorders in elderly people are associated with widespread impairments in physical, psychological, social, and cognitive health. Among elderly people, sociodemographic factors associated with alcohol use disorders include being male, socially isolated, single, and separated or divorced (19). Serious medical disorders among elderly people who misuse alcohol are much more common than the overall population of similar age. Heavy drinker elderly people have more major illnesses, poorer self-perceived health status, more visits from the physicians, more depressive symptoms, less satisfaction with life, and smaller social networks than younger drinkers, non-heavy drinkers and people who have never drunk (19-21).

Almost all patients did not continue to be hospitalized for the time required for SUD treatment. The possible causes may be somatic symptoms, side effects, vegetative symptoms due to deprivation and withdrawal. The majority of patients had more than one hospitalization. It is known that relapses are common after SUD treatment in the world and in our country. Ramo et al. (22) reported that relapses were more frequent among users of alcohol and non-cannabis substances. Patients in whom the relapse occurred earlier were those who did not see substance use as a problem. Patients with early relapses were more introverted. Again, Ramo et al. (22) stated that life stress, conflicts, negative emotional states were associated with relapse. Decker et al. (23) stated that comorbid psychiatric conditions and failure to complete residential substance use treatment were associated with higher relapse. Domino et al. (24) reported that the risk of relapse with substance use was increased in patients who had a family history of substance use disorder. Brecht and Herbeck (25) suggested that significant protective factors predicting longer time to relapse included having experienced serious drug-related 
behavioral problems, longer duration of the index treatment episode, and participating in self-help or other treatment during the post-treatment abstinence period; and that risk factors for shorter time to relapse included having a parent with alcohol and/or drug use problems.

Substance use causes individuals to behave in a manner that does not recognize rules, acts as a harm to themselves and the environment, and leads to crime. Sometimes the substance is used to undermine the control mechanism of consciousness during the crime. Deposits, theft, murder, prostitution and other crimes are also committed in order to obtain the money needed to buy the substance $(26,27)$. One of the leading sources of violent behaviour is drug abuse. Alcohol and substance use, aggression and violent acts have been found to escalate each other. Amphetamines, cocaine and hallucinogens play a direct role in the emergence of aggressive and violent acts by their chemical effects. As a result of the weakening of the control mechanisms on the human brain or the emergence of an intense energy state, individuals can be more aggressive and uncontrolled (28). Many researches have been conducted to investigate the relationship between substance use and crime and it has been demonstrated that there is a relationship between drug use and crime (29). In our study, the majority of patients $(78.3 \%)$ had a history of forensic events. The forensic history was significantly lower in the AUD group than in the other groups. Homicidal behaviour was significantly higher in patients with forensic history. The forensic history was lower in the AUD group. Chen and Wu (30) suggested that there was a positive association between the frequency of substance use and the odds of engaging in gunrelated behaviours. Walters (31) suggested that illicit drug use at year two predicted an increase in arrests between the first and third years of the analysis and arrests at year two predicted an increase in illicit drug use over this same time period. Walters (31) stated that alcohol use failed to predict a change in arrests and arrests failed to predict a change in alcohol use. Lee and Lee (32) reported that participants' rates of alcohol and drug use were higher among those who experienced violence victimization than those who did not.

There are two critical points in the treatment of substance dependence. The first is to control the withdrawal crisis, and the second is to prevent the relapse in the recovered patient. The deprivation crisis is a critical factor in maintaining substance dependence. Tolerance develops in a short time to the effects of abused substances. The growing tolerance contributes to the rapid establishment of physical dependence with more substance intake. The substance-seeking behaviour at the beginning is intended to avoid the complete deprivation of crisis. Control of the deprivation crisis is extremely important in terms of eliminating the need for substances $(33,34)$. Considering the effects of addictive substances in terms of brain neurochemistry, the fact that almost all known neurotransmitters from GABA, serotonin, noradrenaline to glutamate are related to substance dependence and that many genetic, social, cultural and behavioural factors make substance dependence very complicated. It is too optimistic to think that such a complex brain problem can be treated with a single miracle drug in a radical way (35). Antidepressants and some antipsychotics, which are not addictive over time, can be used as preventive or adjuvant therapy at various stages of drug addiction (36). In our study, the majority of patients were treated with antipsychotics. Because of the homicidal behaviour of the patients, antipsychotic use was needed. Some patients were treated for agitation (hibernation). Some patients also had psychotic symptoms. The use of anxiolytic and antipsychotic drugs was needed for the treatment of psychotic symptoms.

Cannabis is a toxic substance for the central nervous system. Cannabis use has been associated with decreased intelligence and brain function. It has been reported that there is a complex relationship between cannabis use and schizophrenia, and this is only partially clarified (37). Murray et al. (38) found that cannabis use was associated with increased psychotic symptoms and increased risk of psychosis, such as schizophrenia. It has been proven that long-term cannabis use causes neurocognitive impairment in healthy individuals and increases the risk of psychosis. In our study, the need for hibernation was significantly higher in the CUD group. Homicidal behaviour was significantly higher in the CUD and IUD groups. Psychotic symptoms were significantly higher in the CUD group.

The prevalence of substance-related disorders is increasing in the world and in our country.

\section{Conclusion}

This study addressed the characteristics of patients with substance use treated in an AMATEM service in our province. Physicians interested in the treatment process of substance use disorders should question the psychiatric comorbidities. In order to obtain more detailed information on this subject, studies with large patient groups are needed.

\section{Ethics}

Ethics Committee Approval: Ethics committee approval was obtained from Adryaman University Non-Invasive Clinical Research Ethics Committee for this study (2019/3-6).

Informed Consent: Informed consent form has been signed.

Peer-review: Externally peer reviewed.

\section{Authorship Contributions}

Concept: M.H.Ö., Design: O.B.E., M.H.Ö., M.Z.K., Data Collection or Processing: O.B.E., M.H.Ö., M.Z.K., Analysis or Interpretation: O.B.E., M.Z.K., Literature Search: O.B.E., M.H.Ö., M.Z.K., Writing: M.H.Ö.

Conflict of Interest: No conflict of interest was declared by the authors.

Financial Disclosure: The authors declared that this study received no financial support. 


\section{References}

1. Johannessen DA, Nordfjærn T, Geirdal AØ. Change in psychosocial factors connected to coping after inpatient treatment for substance use disorder: a systematic review. Subst Abuse Treat Prev Policy 2019; $14: 16$.

2. Ozen ME, Kalenderoglu A, Orum MH, Egilmez OB. Topiramate add-on for treatment of migraine-type headache cures alcohol dependence: A case report. Journal of Mood Disorders (JMOOD) 2017;7:241-2.

3. Orum MH, Kustepe A, Kara MZ, Dumlupinar E, Egilmez OB, Ozen $\mathrm{ME}$, et al. Addiction profiles of patients with substance dependency living in Adiyaman province. Med Science 2018;7:369-72.

4. Orum MH, Kara MZ, Egilmez OB, Kalenderoglu A. Complete blood count alterations due to the opioid use: what about the lymphocyterelated ratios, especially in monocyte to lymphocyte ratio and platelet to lymphocyte ratio? J Immunoassay Immunochem 2018;14:1-12.

5. Madeo G, Bonci A. Rewiring the addicted brain: Circuits-based treatment for addiction. Cold Spring Hasb Symp Quant Biol 2019. pii: 038158.

6. Orum MH, Kara MZ, Egilmez OB. Relationship between immune cells and alcohol dependents and controls: what about the lymphocyterelated ratios? J Immunoassay Immunochem 2018;39:348-50.

7. Orum MH, Kara MZ, Egilmez OB, Ozen ME, Kalenderoglu A. Evaluation of probation implementations of drug users in Adiyaman university training and research hospital: A one-year retrospective study. Med Science 2018;7:754-8.

8. Ozen ME, Orum MH, Kalenderoglu A, Atmaca M. Attentiondeficit/hyperactivity disorder in patients attending remedial treatment due to substance use disorder in Adiyaman University Training and Research Hospital. Psychiatry and Behavioral Sciences 2018;8:57-62.

9. Özen ME, Örüm MH, Kalenderoğlu A. Hot shower therapy in cannabinoid hyperemesis syndrome: A case report. FNG \& Bilim Tip Dergisi 2018;4:142-4.

10. Kustepe A, Kalenderoglu A, Celik M, Kaya-Bozkurt E, Orum MH, Uguz S. Evaluation of impulsivity and complex attention functions of subjects with substance use: Sample from Adiyaman province. Med Science 2019;8:67-71.

11. Örüm MH, Kara MZ, Örüm G, Eğilmez OB. Biperiden bağımlılığı ve nöroleptik malign sendrom ile ayırıcı tanısı: Olgu sunumu. FNG \& Bilim Tip Dergisi 2018;4:194-6.

12. Örüm MH, Kara MZ, Kuştepe A, Kalenderoğlu A. Bilişsel hatalar ve dikkat-eksikliği hiperaktivite bozukluğu belirtilerinin madde kullanım özellikleri ile ilişkisi. Bağımlılık Dergisi-Journal of Dependence 2019;20:47-60.

13. Egilmez OB, Örüm MH, Kara MZ. Adıyaman ili AMATEM verilerinin geriye dönük olarak incelenmesi: 2018 yılı verileri. Bağımlılık Dergisi - Journal of Dependence 2019;20:88-96.

14. Egilmez OB, Örüm MH, Dumlupınar E, Egeli A. Denetimli serbestlik uygulaması kapsamında yapılan başvuruların geriye dönük olarak değerlendirilmesi: 2018 yılı verileri. Bağımlılık Dergisi Journal of Dependence 2019;20:80-7.

15. Savaşan A, Engin E, Ayakdası D. Bir amatem kliniğinden taburcu olan bağımlı hastaların yaşam tarsi değişiklikleri ve nüks durumları. Psikiyatri Hemşireliği Dergisi 2013;4:75-9.
16. Karaagac H, Esenkaya-Usta Z, Usta A, Gümüş-Yarmalı M, Godekmerdan A. Retrospective analysis of sociodemographic characteristics of inpatients at Kayseri Research and Training Hospital AMATEM Clinic. Dusunen Adam 2017;30:251-7.

17. Bulut M, Savaş HA, Cansel N, et al. Gaziantep Üniversitesi alkol ve madde kullanım bozuklukları birimine başvuran hastaların sosyodemografik özellikleri. Bağımlılık Dergisi 2006;7:65-70.

18. American Psychiatric Association. Diagnostic and Statistical Manual of Mental Disorders, 5th edition (DSM-5). Washington, DC, American Psychiatric Association, 2013.

19. O'Connell H, Chin AV, Cunningham C, Lawlor B. Alcohol use disorders in elderly people-redefining an age old problem in old age. BMJ 2003;327(7416):664-7.

20. Goldstein MZ, Pataki A, Webb MT. Alcoholism among elderly persons. Psychiatr Serv 1996;47:941-3.

21. Saunders PA, Copeland JR, Dewey ME, Davidson IA, McWilliam $\mathrm{C}$, Sharma V, et al. Heavy drinking as a risk factor for depression and dementia in elderly men. Findings from the Liverpool longitudinal community study. Br J Psychiatry 1991;159:213-6

22. Ramo DE, Anderson KG, Tate SR, Brown SA. Characteristics of relapse to substance use in comorbid adolescents. Addict Behav 2005;30:1811-23.

23. Decker KP, Peglow SL, Samples CR, Cunningham TD. Longterm outcomes after residential substance use treatment: Relapse, morbidity, and mortality. Mil Med 2017;1821589-95.

24. Domino KB, Hornbein TF, Polissar NL, Renner G, Johnson J, Alberti S, et al. Risk factors for relapse in health care professionals with substance use disorders. JAMA 2005;293:1453-60.

25. Brecht ML, Herbeck D. Time to relapse following treatment for methamphetamine use: a long-term perspective on patterns and predictors. Drug Alcohol Depend 2014;139:18-25.

26. Choenni V, Hammink A, van de Mheen D. Association between substance use and the perpetration of family violence in industrialized countries: A systematic review. Trauma Violence Abuse 2017; 18:37-50.

27. Ozen ME, Orum MH, Kalenderoglu A. Difficult patient in psychiatry practice: A case-control study. Adıyaman Üni Sağlık Bilimleri Derg 2018;4:1064-73.

28. Stoddard SA, Epstein-Ngo Q, Walton MA, Zimmerman MA, Chermack ST, Blow FC, et al. Substance use and violence among youth: a daily calendar analysis. Subst Use Misuse 2015;50:328-39.

29. Löfving-Gupta S, Willebrand M, Koposov R, Blatný M, Hrdlička $\mathrm{M}$, Schwab-Stone $\mathrm{M}$, et al. Community violence exposure and substance use: cross-cultural and gender perspectives. Eur Child Adolesc Psychiatry 2018;27:493-500.

30. Chen D, Wu LT. Association between substance use and gun-related behaviors. Epidemiol Rev 2016;38:46-61.

31. Walters GD. Does drug use inhibit crime deceleration or does crime inhibit drug use deceleration? A test of the reciprocal risk postulate of the worst of both worlds hypothesis. Subst Use Misuse 2018;53:1681-7.

32. Lee Y, Lee KS. Associations between history of hospitalization for violence victimization and substance-use patterns among adolescents: 
A 2017 Korean National Representative Survey. Int J Environ Res Public Health 2018;15. pii: E1543.

33. Soyka M, Mutschler J. Treatment-refractory substance use disorder: Focus on alcohol, opioids, and cocaine. Prog Neuropsychopharmacol Biol Psychiatry 2016;70:148-61.

34. Klein JW. Pharmacotherapy for substance use disorders. Med Clin North Am 2016;100:891-910.

35. Gardner EL. Addiction and brain reward and antireward pathways. Adv Psychosom Med 2011;30:22-60.
36. Bernstein SL, D’Onofrio G. Screening, treatment initiation, and referral for substance use disorders. Addict Sci Clin Pract 2017;12:18.

37. Hosseini S, Oremus M. The effect of age of initiation of cannabis use on psychosis, depression, and anxiety among youth under 25 years. Can J Psychiatry 2019;64:304-12.

38. Murray RM, Englund A, Abi-Dargham A, Lewis DA, Di Forti M, Davies C, et al. Cannabis-associated psychosis: Neural substrate and clinical impact. Neuropharmacology 2017;124:89-104. 